\title{
5. GEOPHYSICAL RECONNAISSANCE SURVEY FOR ODP LEG 117 IN THE NORTHWEST INDIAN OCEAN 1
}

\author{
Gregory S. Mountain ${ }^{2}$ and Warren L. Prell ${ }^{3}$
}

\begin{abstract}
Cruise 2704 of the Robert D. Conrad (RC2704) in the spring of 1986 acquired reconnaissance data necessary for the location and interpretation of ODP Leg 117 drill sites. In addition, three regions were examined in detail using underway geophysical techniques, and geologic and hydrologic samples were collected while on station. These regions include (1) a channel/levee complex of the Indus Fan, (2) the western flank of Owen Ridge, and (3) the southeastern margin of Oman. This report represents preliminary analysis of the underway geophysical data. The first of the three surveys adds to the growing knowledge of meandering channels recently discovered in other deep-sea fans. Tied to DSDP Site 224, the Owen Ridge survey documents the age and nature of uplift of the ridge. Speculations concerning the age of Owen Basin, integrated with survey data offshore Oman and published reports of onshore geology, provide a new hypothesis concerning the multiphase tectonic history of the northwest Indian Ocean.
\end{abstract}

\section{INTRODUCTION}

High wind stress of the summer monsoon strongly influences the regional oceanography of the northwest Indian Ocean, producing strong seasonal upwelling and high surface productivity. RC2704 of the Robert D. Conrad was designed to examine relationships between this seasonal climate pattern and long-term changes in productivity, hydrography, and sediment accumulation. The recovery of representative surficial sediments is essential to the accurate reconstruction of this record, and therefore, reconnaissance survey data were collected and examined prior to coring. A variety of underway and station data were gathered during the 37 days at sea. Continuous measurements of magnetics, gravity, Sea Beam bathymetry, and $3.5-\mathrm{kHz}$ sonograms were collected along the $10,500 \mathrm{~km}$ of ship track out from and returning to Colombo, Sri Lanka (Fig. 1). In addition, $6600 \mathrm{~km}$ of digitally recorded water gun seismic-reflection profiles and seven sonobuoy measurements of sound velocity were acquired within and between the three survey grids. Station work acquired a total of 30 piston cores ( 3 to $15 \mathrm{~m}$ long), 22 giant gravity cores (4 in. diameter), six box cores, four plankton tows, three trigger gravity cores ( 1 in. diameter), and three hydrocasts (Table 1). Three areas were examined in detail: a channel/levee complex of the Indus Fan, the southern Owen Ridge, and the southeast Oman margin. The following is a summary of the results of this three-part survey.

\section{INDUS FAN}

\section{Background}

The Indus Fan is the second largest submarine fan in the world (Barnes and Normark, 1985). It is fed by sediments coming primarily from the Indus River, where until recently (before upstream damming) sediment discharge was comparable to that of the Mississippi River (Lisitzin, 1972). Fan sediments reach as far south as the flanks of the Carlsberg Ridge and extend from the Indian margin to the eastern escarpment of Owen Ridge (Fig.

\footnotetext{
${ }^{1}$ Prell, W. L., Niitsuma, N., et al., 1989. Proc. ODP, Init. Repts., 117: College Station, TX (Ocean Drilling Program).

${ }^{2}$ Lamont-Doherty Geological Observatory, Palisades, NY 10964.

${ }^{3}$ Department of Geological Sciences, Brown University, Providence, RI
}

1). Sediment thickness reaches a maximum of $6.0 \mathrm{~s}$ of reflection time near the main depocenter at $23^{\circ} \mathrm{N}$; it decreases steadily southward with the exception of thin cover above the ChagosLaccadive and Lakshmi ridges (Kolla and Coumes, 1987). Initial intercontinental collision between India and Asia dates from the middle Eocene (Molnar and Tapponnier, 1975; Patriat and Achache, 1984), and consequently it is assumed that the Indus Fan began to develop at this time. The underlying oceanic crust is post-middle Cretaceous in age (Norton and Sclater, 1979), implying that the preceding measurements of total sediment accumulation include some indeterminate amount of pre-fan sediment as well.

The grid surveyed in detail during RC2704 lies near the 4000$\mathrm{m}$ contour of the Indus Fan, $100 \mathrm{~km}$ east of Owen Ridge (Fig. 1). The seafloor gradient in this region is 1:1055 (Kolla and Coumes, 1987). On the basis of gradient alone, the survey grid is placed at the uppermost part of the lower fan; on the basis of echo character, however, the grid is well within the lower fan (Kolla and Coumes, 1987). Ship crossings are too sparse to allow the many channels of this region to be traced between tracks. Nonetheless, Kolla and Coumes (1987) noted an especially large number of channels between the 4000- and 4400-m isobaths. Typical channel-to-levee heights are $30-40 \mathrm{~m}$ on the middle fan, whereas most heights on the lower fan are $20 \mathrm{~m}$ or less.

\section{Bathymetry}

Several tens of distributary channels of the Indus Fan were crossed during the outbound transit to the first survey area on Owen Ridge. Each channel is characterized by an axis from one to several kilometers wide, bounded by roughly symmetric levees that are tens of meters high. In most instances the channel axis is within a few meters of the water depth of the surrounding interchannel region. Most $3.5-\mathrm{kHz}$ sonograms from between channel/levee complexes show a prolonged surface echo with few to no sub-bottom reflectors. This echo character implies that sand/ silt beds roughly 5 to $10 \mathrm{~cm}$ thick comprise about $25 \%$ of the upper few tens of the sediment column (Kolla and Coumes, 1987). In contrast, internal acoustic structure can be seen on many levee crests, which are consequently interpreted as being composed of more uniformly fine-grained sediment.

An especially broad, symmetric channel/levee system that had been crossed on the outbound transit was chosen for a brief survey during the return to Colombo (Fig. 1). The elevated levee 


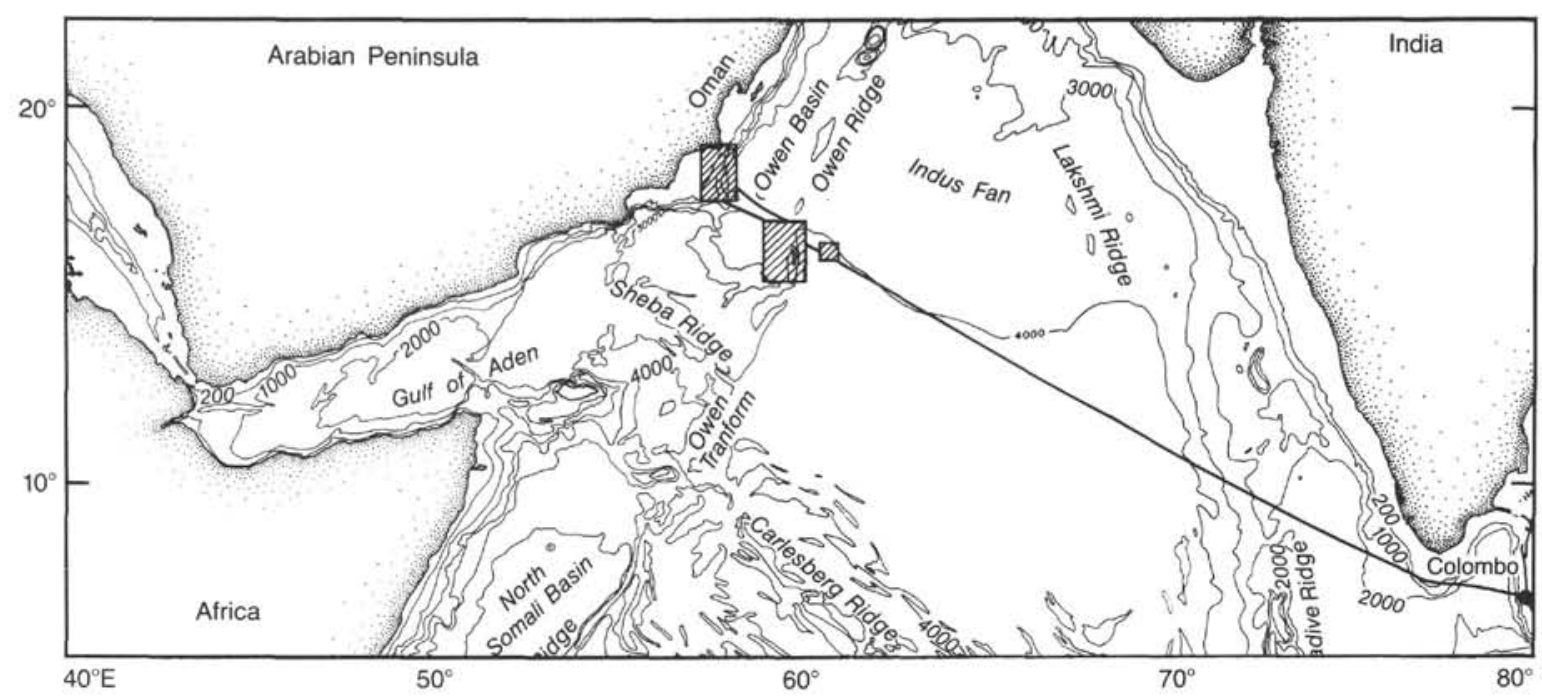

Figure 1. Bathymetry of the northwest Indian Ocean showing the ship track and three detailed surveys of RC2704.

system is roughly $40 \mathrm{~km}$ wide. As the ship approached the channel axis, it was possible to observe both levee flanks on the realtime Sea Beam contour plot, and guided by this image, the vessel was maneuvered so as to follow the channel axis as closely as possible. Whereas the channel deepens gradually and uniformly in the down-fan direction, levee crests vary in water depth and shape in small and irregular ways. Four of eight crossings of the channel show different levee heights; in three of these four, the western crest is higher by 3 to $5 \mathrm{~m}$. The variable character of the levees probably resulted from localized slumping into the channel and/or evulsion of channelized flows and the development of crevasse splays (Damuth et al., 1983). The resulting bathymetric chart (Fig. 2) shows a meandering channel with the characteristics summarized in Table 2. Similar measurements from the Amazon Fan are listed for comparison.

The most notable feature of this Indus Fan channel is that it is unusually wide to be located in such deep water so far from the feeder channel. Several facts imply it is no longer an active conduit for turbidity currents: (1) the small channel gradient, (2) the irregular channel walls, (3) the variable levee heights, and (4) the channel axis roughly $10 \mathrm{~m}$ deeper than the surrounding interchannel region. The latter suggests other channel systems are delivering sands and silts to the survey area, and although the abandoned channel remains isolated, the interchannel regions are aggrading at present. In an effort to monitor accumulation rates, age, and sediment type, a single piston core was taken in the acoustically stratified levee.

Core RC27-62 (3997 m water depth; $11.8 \mathrm{~m}$ long) from the eastern levee (Fig. 2) reveals several sediment characteristics that are unusual for fan cores. First, it has an anomalously high carbonate content (about 45\%) with an upward-increasing trend. Second, its carbonate stratigraphy can readily be correlated to cores on the Owen Ridge. This correlation indicates that the stratigraphic record is relatively continuous and extends back about $425,000 \mathrm{yr}$. The average accumulation rate for this interval is only about $2.7 \mathrm{~cm} / 1000 \mathrm{yr}$, far below that of most fans. Third, the core has only a few of the discrete sand or silt beds that indicate turbidite or overbank deposition, even during glacial low stands of sea level. We infer from these observations that this western Indus Fan tributary-levee system has been inactive for almost $400,000 \mathrm{yr}$.

\section{Seismic Profiling}

Single-channel reflection profiles collected across the Indus Fan during RC2704 reveal more than 1 s of acoustically strati- fied sediment (Fig. 3). No high-amplitude reflectors such as those reported beneath meandering channels in both the Mississippi and Amazon fans as either real or acoustic artifacts (Kastens and Shor, 1985; Flood and Damuth, 1987; Flood, 1987) occur in the RC2704 survey area. Channel/levee complexes of the Indus Fan that are similar in dimension and acoustic character to those on the seafloor are observed down to 0.3-s sub-bottom reflection time (Fig. 3). Such structures are recognized by the onlap of horizontal or gently dipping reflectors onto a zone of weak, often irregular reflectors; the center of each of these zones of weak reflectors is usually chaotic, suggesting that slumping of channel walls accompanies the burial of channel axes. Several strong reflectors beneath the Indus Fan have moderately extensive continuity (several tens to a few a few hundred kilometers), indicating sand-rich deposits of former interlevee regions or unchannelized lower fan deposits now overstepped by the middle fan.

A sonobuoy deployed at the departure of the survey grid detected a strong reflector at 2.9-s sub-bottom traveltime. The graphically measured refraction velocity from beneath this surface measured $4.8 \mathrm{~km} / \mathrm{s}$, suggesting that it marks the top of oceanic crust. This burial depth is slightly more than the roughly $2.3 \mathrm{~s}$ of sediment reported for this region by Kolla and Coumes (1987).

\section{OWEN RIDGE}

\section{Background}

Owen Ridge is composed of elevated oceanic crust dividing the Indus Fan from Owen Basin. To the south it aligns with the Owen Transform Fault offsetting the Carlsberg and East Sheba ridges (Fig. 1; Matthews, 1966); to the north it curves east and merges with Murray Ridge (Barker, 1966). The generalized trend of Owen Ridge is slightly oblique to the southeast Oman margin; consequently the width of Owen Basin decreases northward from roughly 260 to $200 \mathrm{~km}$. Considerable along-strike variability in depth occurs along the crest of Owen Ridge: a minimum of $1890 \mathrm{~m}$ was measured during RC2704, but elsewhere it stands only a few hundred meters above the approximately $3500-\mathrm{m}$ water depths of the Owen Basin. In cross section, Owen Ridge is a dramatically asymmetric feature along much of its length. Within the study area its western flank is covered by about $1 \mathrm{~km}$ of sediment, and a fairly uniform seafloor dip of roughly $2^{\circ}$ is maintained westward to Owen Basin. Its eastern flank is an especially steep $\left(>15^{\circ}\right)$ drop to the Indus Fan, with bare-rock outcrops and few interrupting terraces. 
Table 1. Station summary, RC2704.

\begin{tabular}{|c|c|c|c|c|c|c|}
\hline & Station ${ }^{\mathrm{a}}$ & Day/Time & $\begin{array}{l}\text { Latitude } \\
\text { (N) }\end{array}$ & $\begin{array}{l}\text { Longitude } \\
\text { (E) }\end{array}$ & $\begin{array}{l}\text { Water } \\
\text { depth } \\
\text { (m) }\end{array}$ & $\begin{array}{l}\text { Recovery }{ }^{\mathrm{b}} \\
\text { (m) }\end{array}$ \\
\hline 2 & H-1 & $140 / 10: 59$ & $17^{\circ} 29.5^{\prime}$ & $58^{\circ} 02.8^{\prime}$ & 2020 & 8 ВОТ, 0-600 \\
\hline 3 & $\mathrm{H}-2$ & $140 / 14: 30$ & $17^{\circ} 30.3^{\prime}$ & $58^{\circ} 03.5^{\prime}$ & 2092 & 8 ВОТ, $600-2000$ \\
\hline 4 & $\mathrm{C}-2 \mathrm{PC}$ & $145 / 06: 34$ & $17^{\circ} 41.6^{\prime}$ & $57^{\circ} 52.6^{\prime}$ & 1474 & 5.94 \\
\hline 5 & C-3GGC & $145 / 08: 17$ & $17^{\circ} 40.5^{\prime}$ & $57^{\circ} 53.0^{\prime}$ & 1473 & 0.00 \\
\hline 6 & C-4PC & $145 / 11: 17$ & $17^{\circ} 38.6^{\prime}$ & $57^{\circ} 43.9^{\prime}$ & 1276 & 5.93 \\
\hline 7 & C-5GGC & $145 / 12: 43$ & $17^{\circ} 38.7^{\prime}$ & $57^{\circ} 42.9^{\prime}$ & 1275 & 0.00 \\
\hline 8 & C-6GGC & $145 / 15: 14$ & $17^{\circ} 37.7^{\prime}$ & $57^{\circ} 43.0^{\prime}$ & 1275 & 0.28 \\
\hline 9 & C-7PC & $145 / 17: 43$ & $17^{\circ} 42.9^{\prime}$ & $57^{\circ} 37.6^{\prime}$ & 965 & 10.10 \\
\hline 10 & C-8GGC & $145 / 19: 14$ & $17^{\circ} 42.6^{\prime}$ & $57^{\circ} 37.3^{\prime}$ & 957 & 1.02 \\
\hline 11 & C-9PC & $145 / 21: 13$ & $17^{\circ} 46.7^{\prime}$ & $57^{\circ} 37.3^{\prime}$ & 891 & 10.38 \\
\hline 12 & C-10GGC & $145 / 22: 23$ & $17^{\circ} 45.8^{\prime}$ & $57^{\circ} 39.5^{\prime}$ & 889 & 1.23 \\
\hline 13 & C-11PC & $146 / 00: 43$ & $17^{\circ} 53.7^{\prime}$ & $57^{\circ} 34.8^{\prime}$ & 861 & 11.04 \\
\hline 14 & $\mathrm{C}-12 \mathrm{PC}$ & $146 / 04: 09$ & $18^{\circ} 03.8^{\prime}$ & $57^{\circ} 37.0^{\prime}$ & 788 & 11.63 \\
\hline 15 & C-13PC & $146 / 07: 25$ & $18^{\circ} 14.6^{\prime}$ & $57^{\circ} 41.0^{\prime}$ & 689 & 10.34 \\
\hline 16 & C-14PC & $146 / 12: 12$ & $18^{\circ} 15.2^{\prime}$ & $57^{\circ} 39.3^{\prime}$ & 590 & 10.92 \\
\hline 17 & C- $15 \mathrm{GGC}$ & $146 / 14: 10$ & $18^{\circ} 15.6^{\prime}$ & $57^{\circ} 39.2^{\prime}$ & 579 & 0.00 \\
\hline 18 & C-16PC & $146 / 16: 30$ & $18^{\circ} 16.1^{\prime}$ & $57^{\circ} 37.8^{\prime}$ & 479 & 10.26 \\
\hline 19 & $\mathrm{C}-17 \mathrm{PC}$ & $146 / 20: 10$ & $18^{\circ} 16^{\prime} 6^{\prime}$ & $57^{\circ} 37.6^{\prime}$ & 438 & 9.81 \\
\hline 20 & C-18GGC & $146 / 21: 57$ & $18^{\circ} 17.8^{\prime}$ & $57^{\circ} 38.6^{\prime}$ & 452 & 0.59 \\
\hline 21 & C-19PC & $146 / 23: 51$ & $18^{\circ} 17.4^{\prime}$ & $57^{\circ} 38.6^{\prime}$ & 459 & 5.77 \\
\hline 22 & $\mathrm{C}-20 \mathrm{PC}$ & $147 / 02: 31$ & $18^{\circ} 16.1^{\prime}$ & $57^{\circ} 33.4^{\prime}$ & 296 & 5.43 \\
\hline 23 & $\mathrm{C}-21 \mathrm{PC}$ & $147 / 05: 41$ & $18^{\circ} 06.6^{\prime}$ & $57^{\circ} 31.8^{\prime}$ & 569 & 12.03 \\
\hline 24 & $\mathrm{C}-22 \mathrm{PC}$ & $147 / 11: 44$ & $18^{\circ} 04.2^{\prime}$ & $57^{\circ} 33.8^{\prime}$ & 749 & 11.25 \\
\hline 25 & C-23PC & $147 / 15: 16$ & $17^{\circ} 59.7^{\prime}$ & $57^{\circ} 35.4^{\prime}$ & 815 & 10.83 \\
\hline 26 & $\mathrm{C}-24 \mathrm{PC}$ & $147 / 19: 40$ & $17^{\circ} 43.1^{\prime}$ & $57^{\circ} 49.2^{\prime}$ & 1416 & 11.74 \\
\hline 27 & C-25PC & $147 / 22: 27$ & $17^{\circ} 37.6^{\prime}$ & $57^{\circ} 39.9^{\prime}$ & 1347 & 10.50 \\
\hline 28 & $\mathrm{C}-26 \mathrm{PC}$ & $148 / 00: 52$ & $17^{\circ} 40.7^{\prime}$ & $57^{\circ} 39.9^{\prime}$ & 1064 & 11.21 \\
\hline 29 & C-27BOX & 148/08:04 & $17^{\circ} 54.5^{\prime}$ & $57^{\circ} 35.5^{\prime}$ & 860 & 0.56 \\
\hline 30 & C-28GGC & $148 / 12: 03$ & $17^{\circ} 54.2^{\prime}$ & $57^{\circ} 35.4^{\prime}$ & 866 & 2.78 \\
\hline 31 & C-29BOX & $148 / 14: 43$ & $17^{\circ} 53.1^{\prime}$ & $57^{\circ} 37.3^{\prime}$ & 868 & 0.00 \\
\hline 32 & C-30BOX & $148 / 18: 47$ & $18^{\circ} 13.0^{\prime}$ & $57^{\circ} 41.0^{\prime}$ & 698 & 0.51 \\
\hline 33 & C-31GGC & $148 / 20: 09$ & $18^{\circ} 12.8^{\prime}$ & $57^{\circ} 41.1^{\prime}$ & 707 & 2.68 \\
\hline 34 & C- 32 GGC & $148 / 22: 30$ & $18^{\circ} 14.3^{\prime}$ & $57^{\circ} 38.7^{\prime}$ & 601 & 0.00 \\
\hline 35 & C-33BOX & $148 / 23: 35$ & $18^{\circ} 13.5^{\prime}$ & $57^{\circ} 38.8^{\prime}$ & 630 & 0.49 \\
\hline 36 & $\mathrm{H}-3$ & $149 / 01: 10$ & $18^{\circ} 12.6^{\prime}$ & $57^{\circ} 38.9^{\prime}$ & 688 & 8 вОТ, 0-600 \\
\hline 37 & C- $34 \mathrm{GGC}$ & $149 / 03: 45$ & $18^{\circ} 13.9^{\prime}$ & $57^{\circ} 35.0^{\prime}$ & 509 & 0.00 \\
\hline 38 & C-35BOX & $149 / 04: 48$ & $18^{\circ} 14.0^{\prime}$ & $57^{\circ} 35.9^{\prime}$ & 498 & 0.42 \\
\hline 39 & C-36TW & $149 / 07: 56$ & $18^{\circ} 19.5^{\prime}$ & $57^{\circ} 30.1^{\prime}$ & 185 & 0.00 \\
\hline 40 & C-37TW & $149 / 08: 22$ & $18^{\circ} 20.5^{\prime}$ & $57^{\circ} 31.2^{\prime}$ & 188 & 0.00 \\
\hline 41 & C-38TW & $149 / 09: 08$ & $18^{\circ} 19.7^{\prime}$ & $57^{\circ} 33.5^{\prime}$ & 247 & 0.15 \\
\hline 42 & C- 39 GGC & $156 / 07: 48$ & $16^{\circ} 37.2^{\prime}$ & $59^{\circ} 51.9^{\prime}$ & 1889 & 3.05 \\
\hline $43+$ & $\mathrm{C}-40 \mathrm{PC}$ & $156 / 09: 23$ & $16^{\circ} 37.2^{\prime}$ & $59^{\circ} 52.1^{\prime}$ & 1890 & 11.40 \\
\hline $44+$ & C-4IGGC & $156 / 12: 31$ & $16^{\circ} 31.7^{\prime}$ & $59^{\circ} 47.3^{\prime}$ & 2052 & 2.01 \\
\hline 45 & C- $42 \mathrm{PC}$ & $156 / 13: 55$ & $16^{\circ} 31.1^{\prime}$ & $59^{\circ} 47.0^{\prime}$ & 2044 & 11.11 \\
\hline 46 & C- 43 GGC & $156 / 16: 49$ & $16^{\circ} 36.2^{\prime}$ & $59^{\circ} 46.0^{\prime}$ & 2159 & 2.45 \\
\hline 47 & $\mathrm{C}-44 \mathrm{PC}$ & $156 / 18: 37$ & $16^{\circ} 36.2^{\prime}$ & $59^{\circ} 46.0^{\prime}$ & 2159 & 11.75 \\
\hline 48 & C- $45 \mathrm{GGC}$ & $156 / 21: 21$ & $16^{\circ} 36.0^{\prime}$ & $59^{\circ} 40.8^{\prime}$ & 2406 & 2.88 \\
\hline 49 & C- $46 \mathrm{PC}$ & $156 / 23: 37$ & $16^{\circ} 38.8^{\prime}$ & $59^{\circ} 42.7^{\prime}$ & 2441 & 10.65 \\
\hline 50 & C-47GGC & $157 / 02: 13$ & $16^{\circ} 38.2^{\prime}$ & $59^{\circ} 41.5^{\prime}$ & 2530 & 2.89 \\
\hline 51 & $\mathrm{C}-48 \mathrm{PC}$ & $157 / 03: 52$ & $16^{\circ} 38.1^{\prime}$ & $59^{\circ} 41.3^{\prime}$ & 2545 & 11.79 \\
\hline 52 & C- $49 \mathrm{GGC}$ & $157 / 06: 12$ & $16^{\circ} 39.1^{\prime}$ & $59^{\circ} 39.1^{\prime}$ & 2686 & 2.94 \\
\hline $53+$ & C-50PC & $157 / 08: 04$ & $16^{\circ} 40.2^{\prime}$ & $59^{\circ} 39.6^{\prime}$ & 2707 & 12.07 \\
\hline 54 & C-51GGC & $157 / 11: 22$ & $16^{\circ} 42.2^{\prime}$ & $59^{\circ} 36.0^{\prime}$ & 2918 & 2.68 \\
\hline 55 & $\mathrm{C}-52 \mathrm{PC}$ & $157 / 13: 22$ & $16^{\circ} 40.8^{\prime}$ & $59^{\circ} 35.9^{\prime}$ & 2985 & 11.89 \\
\hline 56 & C- 53 GGC & $157 / 18: 08$ & $16^{\circ} 32.3^{\prime}$ & $58^{\circ} 27.3^{\prime}$ & $c_{3258}$ & 2.37 \\
\hline 57 & C-54PC & $157 / 20: 31$ & $16^{\circ} 32.1^{\prime}$ & $59^{\circ} 27.3^{\prime}$ & 3275 & 11.76 \\
\hline $58+$ & C-55GGC & $158 / 00: 14$ & $16^{\circ} 28.6^{\prime}$ & $59^{\circ} 21.2^{\prime}$ & 3392 & 2.72 \\
\hline 59 & C-56PC & $158 / 02: 47$ & $16^{\circ} 29.0^{\prime}$ & $59^{\circ} 20.7^{\prime}$ & 3405 & 11.59 \\
\hline 60 & C-57GGC & $158 / 06: 20$ & $16^{\circ} 20.9^{\prime}$ & $59^{\circ} 17.6^{\prime}$ & 3490 & 2.92 \\
\hline 61 & $\mathrm{C}-58 \mathrm{PC}$ & $158 / 08: 28$ & $16^{\circ} 22.0^{\prime}$ & $59^{\circ} 11.2^{\prime}$ & 3484 & 11.84 \\
\hline 62 & C-59BOX & $158 / 12: 07$ & $16^{\circ} 22.0^{\prime}$ & $59^{\circ} 10.9^{\prime}$ & 3488 & 0.00 \\
\hline 63 & C-60GGC & $158 / 21: 04$ & $16^{\circ} 36.8^{\prime}$ & $59^{\circ} 51.5^{\prime}$ & 1887 & 0.93 \\
\hline 64 & C-61PC & $159 / 06: 08$ & $16^{\circ} 39.5^{\prime}$ & $59^{\circ} 31.4^{\prime}$ & 1893 & 15.97 \\
\hline 65 & C- $62 \mathrm{PC}$ & $159 / 21: 22$ & $16^{\circ} 09.6^{\prime}$ & $60^{\circ} 40.8^{\prime}$ & 3997 & 11.78 \\
\hline
\end{tabular}

$\mathrm{a}_{+}=$surface plankton tow $\mathrm{C}=$ core $\mathrm{PC}=$ piston core; $\mathrm{GGC}=$ giant gravity core;

BOX $=$ box core $($ Soutar); $\mathrm{TW}=$ trigger gravity core; $\mathrm{H}=$ hydrographic cast.

b All core lengths are corrected for voids and short sections; BOT = hydrographic sampling bottles.

c $3.5-\mathrm{kHz}$ depth, wire out, and pinger depths do not agree. 


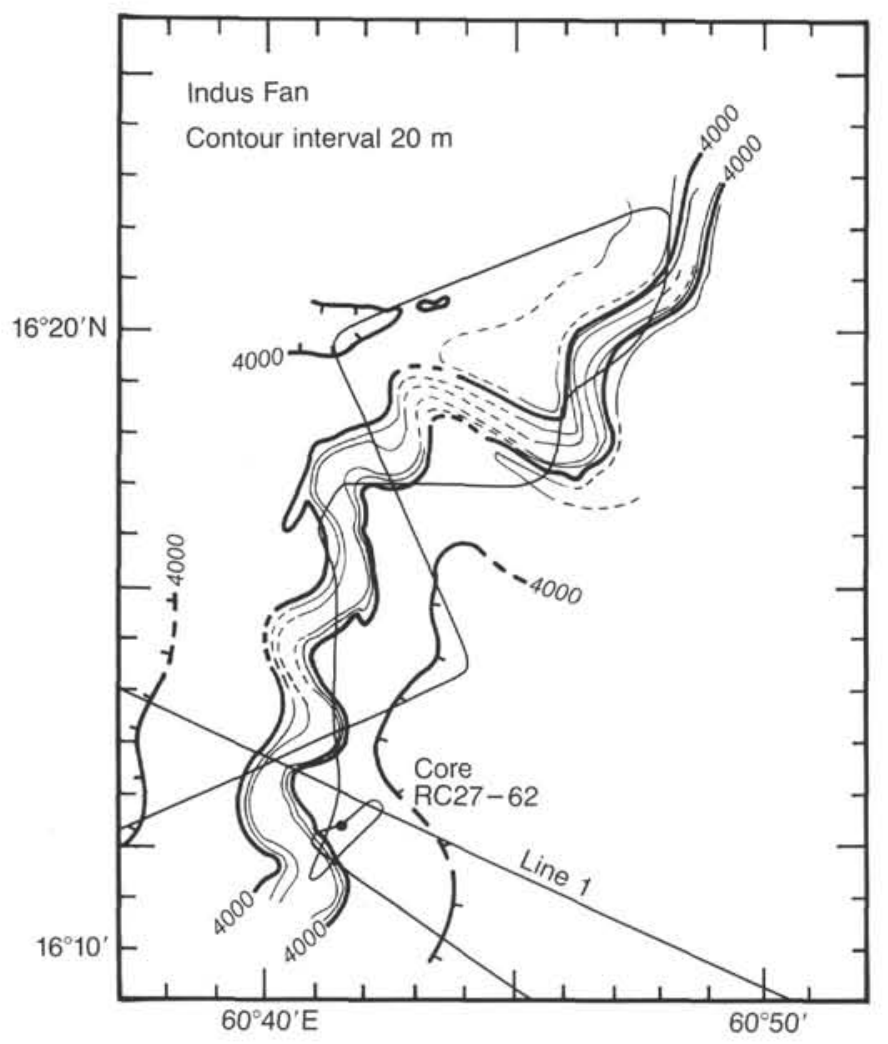

Figure 2. Bathymetry of a meandering channel of the Indus Fan contoured from Sea Beam swath-map soundings. Track-line control and location of piston Core 62 of RC2704 are shown. Single-channel seismic line 1 crosses the channel axis and is shown in Figure 3.

Owen Ridge was an elevated structure at least as far back in time as the middle Miocene. This fact is derived from Deep Sea Drilling Project (DSDP) Site 224 on the west flank of the Ridge, where lower Miocene turbidites were recovered several hundred meters above lateral equivalents traced in seismic profiles from Owen Basin (Whitmarsh, Weser, et al., 1974). The topographic relief maintained at present is consistent with (but not proof of)
Table 2. Channel parameters, Indus and Amazon fans.

\begin{tabular}{|c|c|c|}
\hline Parameter & $\begin{array}{l}\text { Indus } \\
\text { Fan }\end{array}$ & $\begin{array}{l}\text { Amazon } \\
\text { Fan }\end{array}$ \\
\hline Channel to levee crest & $48-71 \mathrm{~m}$ & $10-30 \mathrm{~m}$ \\
\hline Width between opposite levee crests & $8 \mathrm{~km}$ & (Not available) \\
\hline $\begin{array}{l}\text { Width between steepest points of } \\
\text { opposite channel walls }\end{array}$ & $1.8-2.4 \mathrm{~km}$ & $0.4 \mathrm{~km}$ \\
\hline Channel gradient along axis & $1: 4600$ & $1: 550$ \\
\hline Channel gradient in straight line & $1: 3800$ & $1: 280$ \\
\hline Channel sinuousity & 1.2 & 1.8 \\
\hline
\end{tabular}

the role of Owen Ridge as a plate boundary. Many published maps portray Owen Ridge as a fracture zone between the Indian and Arabian plates (with or without transpressional motion at present), based on one or more of the following types of reasoning:

1. Seismic focal mechanisms imply right-lateral motion across the ridge (Sykes, 1968).

2. East Sheba Ridge is spreading slightly faster than Carlsberg Ridge. These segments are offset by the Owens Transform Fault, and if this contrast is maintained across Owen Ridge as well, $2-4 \mathrm{~mm} / \mathrm{yr}$ of right-lateral motion is implied (DeMets and Gordon, 1987).

3. Global solutions for instantaneous rotation poles, yielding right-lateral motion between the Indian and Arabian plates. These, if taken up across Owen Ridge, result in slip rates and convergence rates between a few millimeters and $1-2 \mathrm{~cm} / \mathrm{yr}$ (McKenzie and Sclater, 1971; Chase, 1978; Minster and Jordan, 1978; DeMets and Gordon, 1987, in press).

4. Contrasting marine magnetic anomaly patterns to either side of Owen Ridge demonstrate an early Cenozoic age for the crust beneath Indus Fan, but fail to reveal any identifiable anomalies within the adjacent Owen Basin (Whitmarsh, 1979; Larson et al., 1985).

Accepting Owen Ridge as the boundary between the Indian and Arabian plates has implications concerning the regional tectonic history. Most importantly, this predicts that the crust of Owen Basin is considerably older than that of the adjacent Indus Fan, and indeed, most maps of the area show Mesozoic crust within Owen Basin. This assumption is based on the ap-

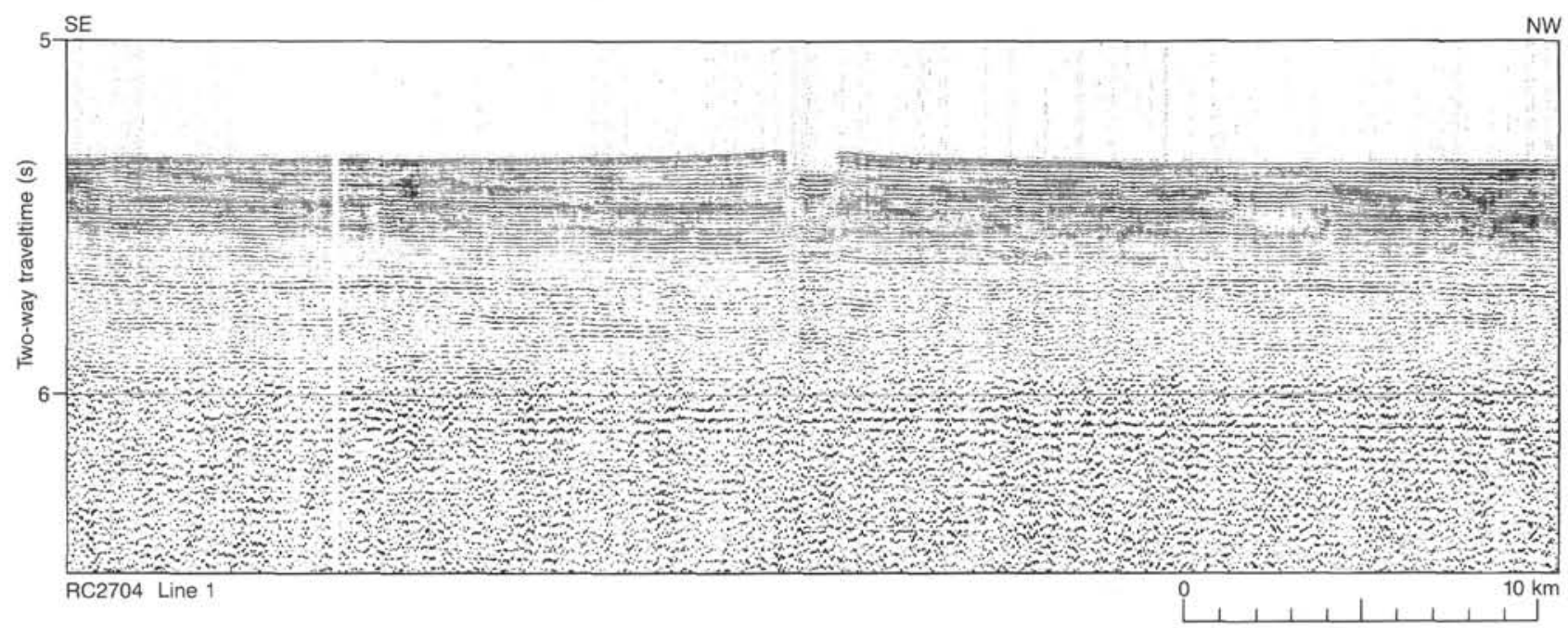

Figure 3. Single-channel seismic line 1 centered on the meandering channel axis mapped in Figure 2. The gently sloping, elevated levees to either side of the channel span the width of this display. Several buried channel axes can be seen down to at least $0.3 \mathrm{~s}$ sub-bottom. 
parent similarities among the several basins of the western Indian Ocean (Owen, North Somali, West Somali, and Mozambique basins). Spreading anomalies within the latter two basins (Segoufin, 1978; Segoufin and Patriat, 1980; Rabinowitz et al., 1983) show conclusively that both formed as east and west Gondwanaland drifted apart in Middle to Late Jurassic time; it is generally assumed that the North Somali and Owen basins formed at this time by the same process (Whitmarsh, 1979; Cochran, 1981; Stein and Cochran, 1985). However, the lack of identifiable spreading anomalies, drill holes, and/or reconnaissance data within Owen Basin leave this history unproven.

The RC2704 survey grid on Owen Ridge was designed to locate suitable targets for bottom sampling. Upwelling that results from the southwest monsoon creates high surface productivity for part of each year in the northwest Indian Ocean; it was anticipated that time-series analysis of productivity patterns in sediment cores would reveal past changes in the monsoon system. The elevation of Owen Ridge above the carbonate compensation depth and the diluting turbidites of the Indus Fan make it ideal for this purpose. A totally unexpected outcome of this survey, however, was that it provided information that casts doubt on a Mesozoic origin for Owen Basin and the adjacent Oman margin.

\section{Bathymetry}

Most of the RC2704 survey lines across Owen Ridge were run in the north-south strike direction so as to minimize the chance of missing narrow features oriented downslope (slump scars, faults, etc.). The $3-\mathrm{km}$ spacing between lines vs. the width of the Sea Beam swath resulted in roughly $75 \%$ bathymetric coverage at the foot of Owen Ridge and $50 \%$ coverage at the crest. The crest of Owen Ridge within the survey area consists of two broad, uniformly sedimented summits slightly shallower than $2000 \mathrm{~m}$ (at $16^{\circ} 40^{\prime} \mathrm{N}$ and $16^{\circ} 10^{\prime} \mathrm{N}$; Fig. 4). These features are separated by a narrow saddle of irregular water depths that coincides with a slight change in trend of the Ridge. Slump scars begin immediately below $2000 \mathrm{~m}$, where the seafloor gradient increases abruptly to about $2^{\circ}$. On the west flank these slump scars broaden downslope toward Owen Basin, and they comprise a significant majority of the seafloor area on this flank. The eastern flank is so precipitous (generally about $15^{\circ}$, and sporadically more than $20^{\circ}$ ) that little sediment cover is detectable on either $3.5-\mathrm{kHz}$ sonograms or on seismic-reflection profiles. Most of the slump scars on the west flank are fairly wide and crudely $U$-shaped; typical values are several kilometers wide and one to several hundred meters deep. These contrast with active canyons typical of continental slopes. The latter are generally $\mathrm{V}$-shaped, have steeper walls, show less downslope change in cross-section, and often have trellislike networks of tributary gullies (Twichell and Roberts, 1982; Farre et al., 1983) that are not detected on Owen Ridge.

\section{Seismic Profiling}

RC2704 reflection profiles on Owen Ridge reveal a history of deposition, uplift, and sediment redistribution. Several northsouth and east-west lines (strike and dip, respectively) are shown in Figure 5 (in the back pocket of this volume) and their dominant features are described here. Along much of the west flank of the Ridge there is a weakly reflective unit $(<0.2 \mathrm{~s}$ thick) separating the irregular reflectors of volcanic basement from the stratified, high-amplitude reflectors of overlying sedimentary units. Total sediment thickness increases from roughly $1.0 \mathrm{~s}$ at the crest to a maximum of $1.6 \mathrm{~s}$ within Owen Basin. However, this pattern varies considerably owing to local basement topography. Three aspects of basement fabric are especially noteworthy: (1) angular onlap onto basement highs (or the reflectorless veneer) shows that basement topography controlled the distri- bution of the oldest (presumably turbidite-rich) stratified units, (2) most of the basement highs are aligned roughly east-west, and (3) despite early infilling of basement topography, the locations of relatively recent slumps down the west flank continue to be influenced by underlying basement features.

We infer from these observations that topographic highs (inherited from either a roughly north-south or east-west spreading ridge) were first covered by a blanket of pelagic sediments and later were smoothed during a period of turbidite deposition (Fig. 6). Differential compaction within the sediment column has since enabled this basement topography to influence the redistribution of sediments. Little evidence suggests that the uplift of Owen Ridge occurred on the local level; to the contrary, it appears that the region covered by the survey grid was elevated rather uniformly, as a single unit. This elevation is revealed by the geometry of reflectors (Fig. 6). Apart from the basement onlap described previously, the most deeply buried sediments maintain uniform thickness up the west flank of Owen Ridge. Regional onlap of sedimentary units onto underlying sedimentary units indicates syndepositional uplift, and this process begins at the level marked with the deeper of the two dotted lines in Figure 5. The seismic interval between the dotted lines consists of numerous high-amplitude reflector units that thin toward the crest of Owen Ridge. These are interpreted as turbidites barely covering a slowly rising structure. The upper set of dots highlights a diachronous surface that is stratigraphically shallower (younger) at the foot of the Ridge than it is at the crest. It is identified in this way to emphasize the conclusion that Owen Ridge emerged from the turbidite plain from east to west. While turbidites (high-amplitude reflectors that converge eastward) were being deposited in Owen Basin, an increasingly larger area of the Ridge was being covered by pelagic sediments (low-amplitude, parallel reflectors.)

The onset of widespread slumping occurs at various stratigraphic levels along Owen Ridge. In the northern part of the survey area, irregular reflectors (slump deposits) showing various types of baselap occur a few tenths of a second above the turbidite/pelagic transition (the upper dotted line in Fig. 5). Along several profiles from the southern part of the survey, this same seismic facies rests directly on the turbidites. Because of the difficulty of tracing reflectors within this irregular and discontinuous unit of slumps, age comparisons between the slumps of the north and south cannot be inferred reliably. Slumping may have begun earlier in the south; alternatively, the process may have been more severe in the south, and more of the underlying pelagic unit was removed than it was in the north.

At the time of RC2704, age control of sediments on Owen Ridge was known only from the spot cores of DSDP Site 224 (Whitmarsh, Weser, et al., 1974; drill site located on line 35, Fig. 5). Approximate ages (Fig. 6) correlated to the seismic units described in this report are as follows. Lower Eocene to lower Oligocene nannofossil chalk rests as a draping unit on volcanic basement. Lower to "mid"-Oligocene turbidites infill this topography; within a few kilometers of Site 224 they are considerably older, perhaps middle or even lower Eocene. The beginning of Owen Ridge uplift (derived from RC2704 data and marked by the lower dotted line in Fig. 5) occurs in the 109-m gap between Cores 224-6 and 224-7, within the upper Oligocene. The turbidite/pelagic transition at Site 224 (the upper dotted line in Fig. 5) is near to the boundary between Cores 224-3 and 224-4, which marks an unconformable lower to middle Miocene contact at the drill site. Seismic profiles do not suggest a stratigraphic gap as large as the approximately $7 \mathrm{Ma}$ hiatus reported at Site 224 (Whitmarsh, Weser, et al., 1974). The onset of widespread slumps, by contrast, is clearly associated with a seismic unconformity, but the spot coring at Site 224 prohibits an age assignment more accurate than late Miocene or younger. 


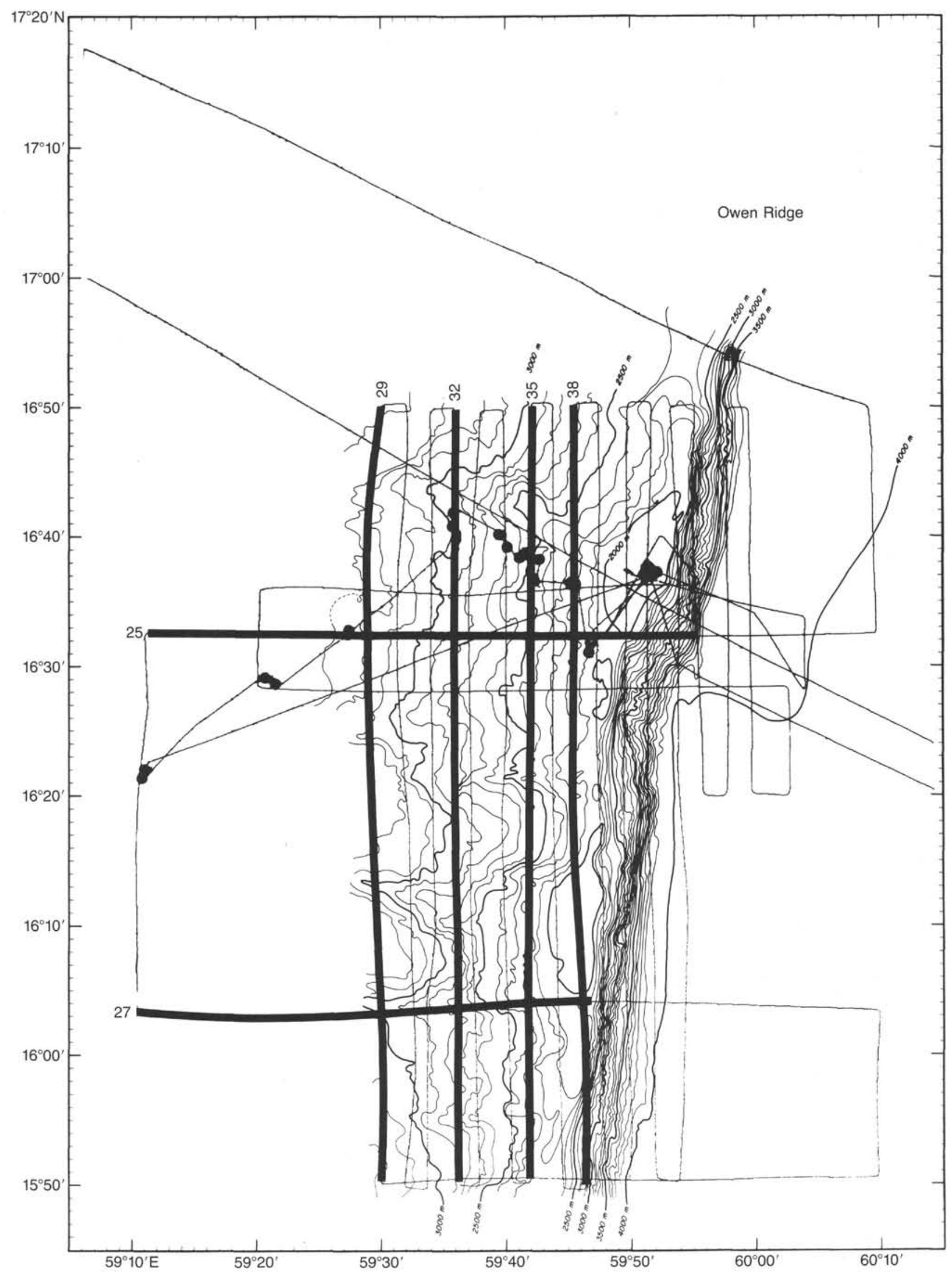

Figure 4. Bathymetry of Owen Ridge contoured from Sea Beam soundings. Track control and piston cores taken on RC2704 are shown. Numbered, bold single-channel seismic profiles are shown in Figure 5 (back pocket). 


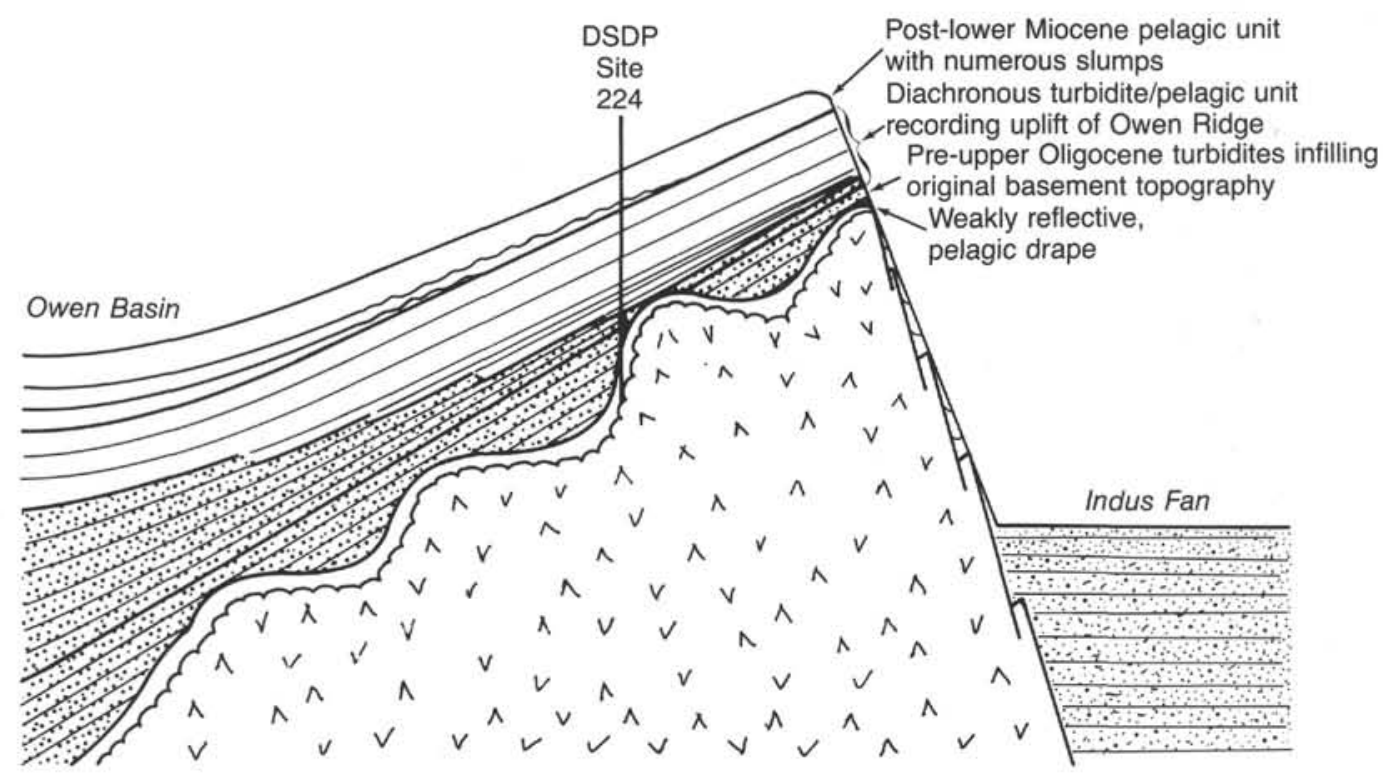

Figure 6. Idealized dip-line profile across Owen Ridge (not to scale).

\section{OMAN MARGIN}

\section{Background}

Prior to RC2704, the topography, sediment character, and sub-bottom structures offshore southeast Oman were not known in detail. Surveys north of $19^{\circ} \mathrm{N}$ had found a narrow shelf and fairly steep slope with uniform northeast strike; gravity and seismic data revealed margin-parallel basins beneath the slope filled with several kilometers of sediment (Whitmarsh, 1979). The few geologic maps of the onshore region showed extensive Quaternary sand cover with outcrops restricted to (1) a window along Masirah Bay (Fig. 7) where pre-Cambrian dolomites, Paleozoic clastics, and Mesozoic marls and limestones crop out in a structurally complex terrain (Gorin et al., 1982) and (2) ophiolites of possible Late Cretaceous age on Masirah Island (Moseley and Abbotts, 1979) and on the headland comprising Ra's Madrakah (Fig. 7; Al-Marjeby and Nash, 1986). The lack of a widespread, encroaching Upper Cretaceous coastal plain, plus the occurrence of ophiolites along the margin raise questions about the accuracy of a Jurassic pull-apart history. This inconsistency is all the more apparent in that transcurrent, margin-parallel faults have appeared on generalized geologic maps for decades (Morton, 1959; Beydoun, 1982). One of these features, the Masirah Fault, cuts across Ra's Madrakah from Masirah Bay and into Siquirah Bay (Fig. 7; Gorin et al., 1982).

Few bottom samples from offshore southeast Oman have been reported in the literature. Based on inference from known patterns of surface productivity and hydrography, similarities to the western margin of India (Setty, 1983), and chemical profiles (Wyrtki, 1973) we expected that the bottom water between 500 and $1500 \mathrm{~m}$ along Oman is very low in dissolved oxygen, perhaps even anoxic. If true, then the scarcity or total lack of bioturbation in these surficial sediments could provide exceptional high-resolution stratigraphy. In anticipation of this opportunity, suitable coring targets were selected within a grid of bathymetric mapping, $3.5-\mathrm{kHz}$ echo-sounding, and single-channel seismic profiles collected during RC2704. As along Owen Ridge, these data provided the necessary survey for bottom sampling, and furthermore, revealed conflicts with the prevailing tectonic history.

\section{Bathymetry}

Similar in design to the Oman Ridge survey, numerous strikedirection lines were run parallel to the Oman margin to identify the dominant downslope bathymetric and structural fabric. The survey extended from the $200-\mathrm{m}$ isobath seaward to $2500 \mathrm{~m}$. Sea Beam coverage was generally less than $25 \%$ of the seafloor area. At the landward edge of the grid, this coverage decreased to less than $5 \%$, but bathymetric complexity in this region is generally simple enough to enable reliable contouring to be made between track lines (Fig. 8).

The bathymetry of the northern and southern extremes of the survey grid contrasts significantly. North of $18^{\circ} 30^{\prime} \mathrm{N}$ there are numerous submarine canyons resembling those typically found along passive continental margins. Most Oman canyons are incised several hundred meters into the slope. Canyon walls face inward with roughly $10^{\circ}$ gradients, and there are at least several "tributary gullies" leading into the major canyons (Twichell and Roberts, 1982; Farre et al., 1983). All canyons have along-axis gradients of $3.5^{\circ}$ to $3.75^{\circ}$; these axes are narrow and clear of debris, indicating recent activity.

That these canyons are restricted to the area adjacent to the narrowest part of the shelf, directly offshore of the headland of Ra's Madrakah, suggests a mechanism for their formation: currents parallel to the shoreline sweep sediment toward the headland and into canyon heads that have long been entrenched in the shelf break. Merely attributing the occurrence of these canyons to eustatic lowering or to times of vigorous fluvial runoff from Oman is insufficient; the density and complexity of the canyons argue for numerous events, meaning a significant period of time (at least hundreds of thousands of years) was required for their formation. Because of the high sedimentation rates of this productive margin (probably tens of centimeters per thousand years), these canyons would be filling up if there were no processes keeping them clear of pelagic and reworked intercanyon sediment. The most likely clearing processes are turbidity currents that result from shelf sediment constantly supplied to canyon heads.

Few canyons traverse the margin south of $18^{\circ} 30^{\prime} \mathrm{N}$. Instead, this region is dominated by a broad, gently sloping $\left(<0.5^{\circ}\right)$ 


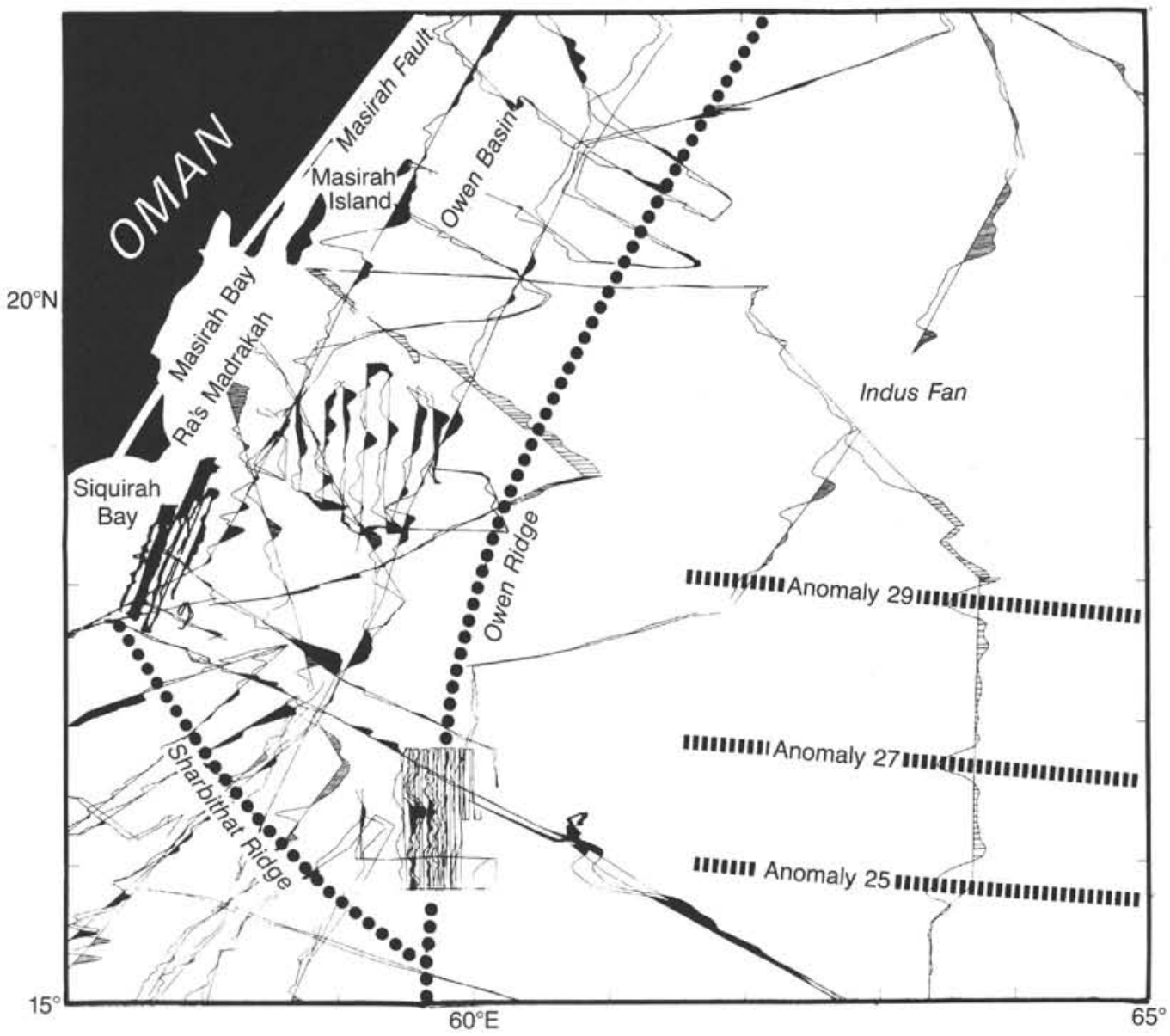

Figure 7. Bathymetry (Canadian Hydrographic Service 1975 GEBCO map series) and magnetic anomalies (up to and including results of RC2704) of Owen Basin and adjacent regions. Despite the west-southwest-east-northeast magnetic fabric in Owen Basin and along the southeast Oman margin (Whitmarsh, 1979), these features have not been correlated to any series of seafloor spreading anomalies. The RC2704 survey offshore Siquirah Bay was several tens of kilometers seaward of the margin-parallel, transcurrent Masirah Fault (Morton, 1959; Beydoun, 1982; Gorin et al., 1982).

"terrace" in a water depth between 700 and $1000 \mathrm{~m}$. A smooth $3.5^{\circ}$ to $3.75^{\circ}$ slope devoid of canyons occurs landward of this area; only one exposed slump scar was identified (on both Sea Beam and 3.5-kHz records; Fig. 5), trending north-south and beginning at $18^{\circ} 23^{\prime} \mathrm{N}, 57^{\circ} 42^{\prime} \mathrm{E}$. Beyond the $1000-\mathrm{m}$ isobath is a steep $\left(7^{\circ}\right.$ to $\left.12^{\circ}\right)$ drop-off and a few narrow incised canyons; generally, broad "amphitheater-type" features indent this part of the margin. Water depths steadily increase seaward of this region, with the exception of an offshore high near $17^{\circ} 40^{\prime} \mathrm{N}$, $57^{\circ} 55^{\prime} \mathrm{E}$. The seaward face of this latter structure is a particularly steep $\left(18^{\circ}\right)$ escarpment trending southwest-northeast, oblique to most other structural trends within the survey grid.

\section{Seismic Profiling}

The "stair-step" bathymetry in the central part of the survey grid is clearly controlled by two underlying lineations approximately beneath the 500 - and 1000 - $\mathrm{m}$ isobaths. The landward lineation is an abrupt, seaward-facing drop in acoustic basement named the Siquirah Fault (Mountain and Prell, in press); the second is a complex of steep-sided, sub-bottom structures that are not crystalline basement (see profiles in Fig. 5). Between these lineations is the gentle midslope "terrace," and in this region basement is too deep to be detected on water gun reflection profiles. Regionally low values of free-air gravity identify this thick depocenter (Fig. 9); two reversed sonobuoy experiments along the axis of this depocenter demonstrate that the sediments are $2.4 \mathrm{~km}$ thick. The landward boundary of this depocenter, the Siquirah Fault, does not follow a perfectly straight trace. Instead, there are several sharp discontinuities mapped here as orthogonal offsets (Fig. 9). The fault deviates landward toward the north and is not crossed in the northern third of the survey. Profiles of $3.5-\mathrm{kHz}$ sonograms show several vertical offsets reach the seafloor immediately above the basement scarp, proving that faulting continues at present. Both the seismic and the gravity data indicate that the midslope depocenter gradually thins northward. The seaward boundary of the depocenter (the complex structures near the $1000-\mathrm{m}$ isobath) can be followed into the northern part of the survey where many of these structures are dissected by slope canyons. As much as $1.0 \mathrm{~s}$ of acoustic stratification can be seen within these features, indicating sedimentary composition. Because of their narrow and complexly faulted character, the internal detail within many of these structures is commonly lost among diffractions, often giving them the misleading appearance of diapirs (e.g., line 15, Fig. 5). Dip-line 18 (Fig. 5) provides the clearest evidence that these structures are actually rotated blocks of comparatively parallel-stratified sediments; their upturned, landward sides terminate in abrupt faults. The onlapping pattern of reflectors along their landward sides demonstrates they are significantly older than most of the sediments comprising the midslope depocenter. That they do not 


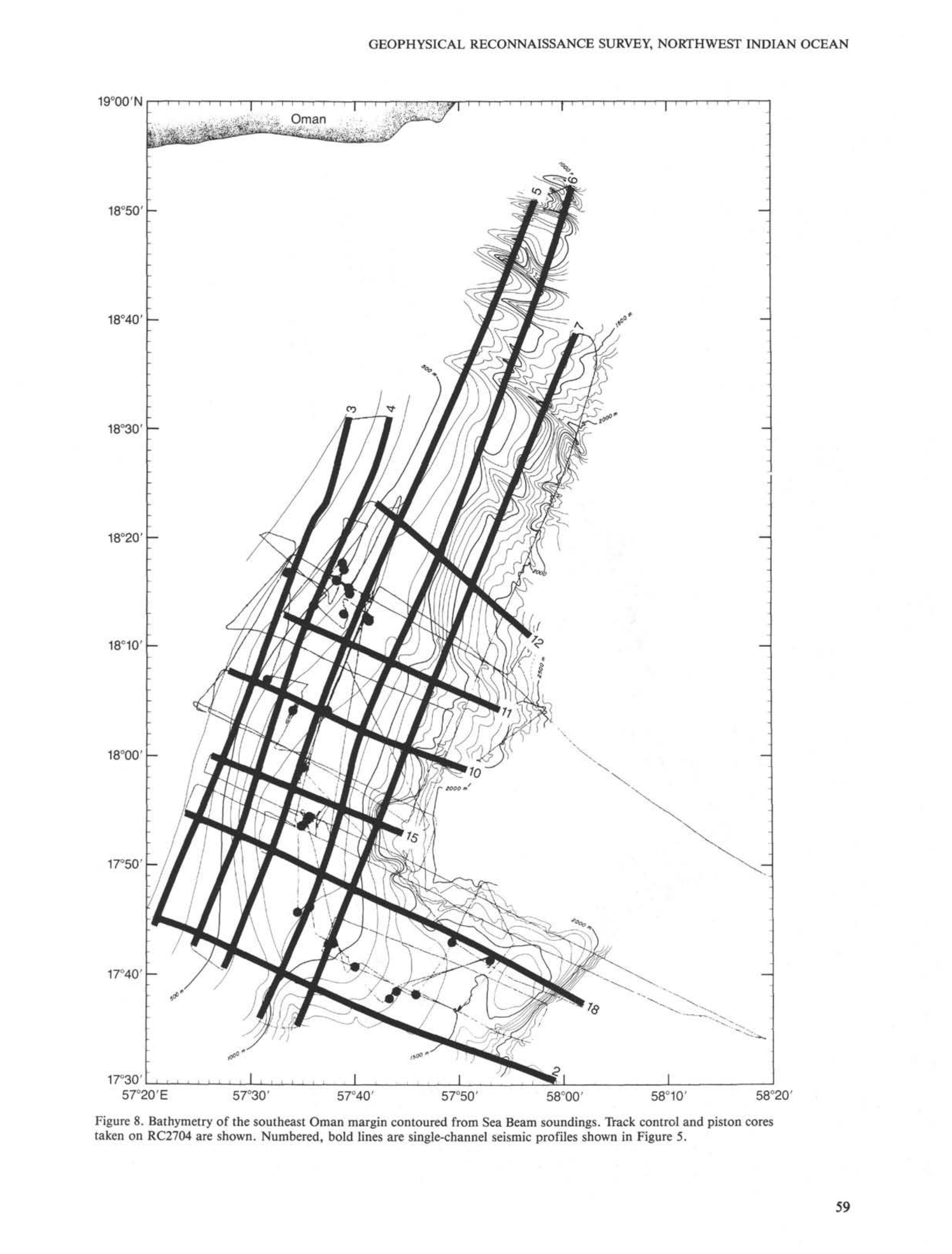




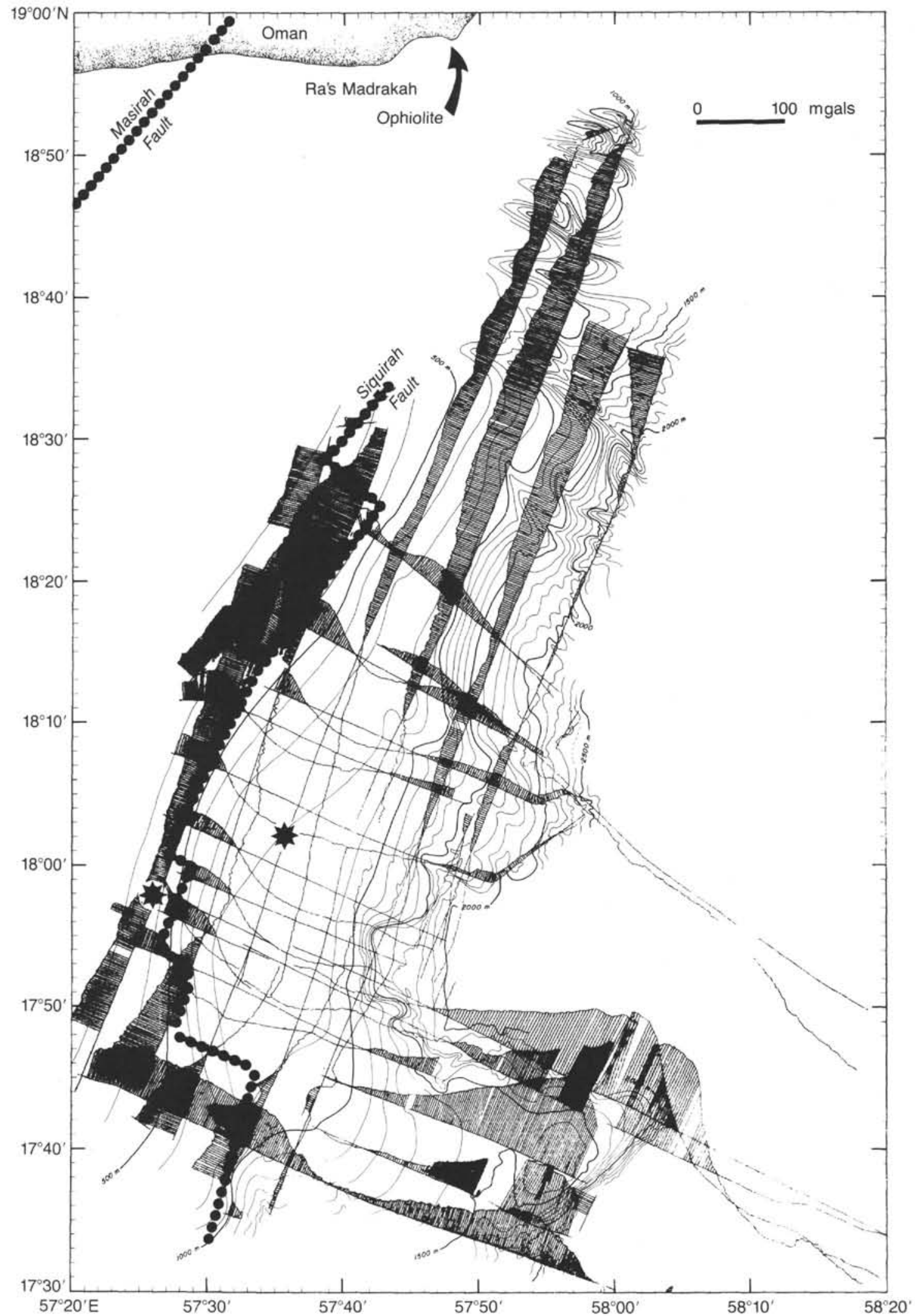

Figure 9. Free-air gravity plotted perpendicular to RC2704 ship tracks. Regional low values beneath the midslope "terrace" outline a depocenter where a reversed sonobuoy experiment (marked by the seaward star) determined $2.4 \mathrm{~km}$ of sediment above a refractor with a velocity of $5.3 \mathrm{~km} / \mathrm{s}$. Another sonobuoy (star symbol landward of the Siquirah Fault) found thin sediments and a basement velocity of $4.8 \mathrm{~km} / \mathrm{s}$. The irregular trace of the Siquirah Fault (Mountain and Prell, in press) was determined with single-channel reflection profiles (see Fig. 5). The Masirah Fault, several tens of kilometers farther landward, was not crossed during RC2704. The northeast extension of the region between these faults intersects Ra's Madrakah and Masirah Island where ophiolites of probable Late Cretaceous-Paleogene age and origin are found (Moseley, 1969; Moseley and Abbotts, 1979; Gorin et al., 1982). 
coincide with free-air gravity anomalies (Fig. 9) suggests basement is not structurally involved to a significant degree. Beyond these first-order observations, however, their exact origin is far from clear with available data.

In general, the term "acoustic basement" has no compositional significance; it simply indicates that deeper reflecting horizons cannot be detected. Refraction and magnetic data from RC2704, however, suggest that acoustic basement along southeast Oman is crystalline rock and in fact may be oceanic crust. Graphically-derived velocities from sonobuoys provide values of 4.6 and $5.3 \mathrm{~km} / \mathrm{s}$, as shown in Fig. 5. The slower value was measured landward of the Siquirah Fault, where the level and shallow nature of acoustic basement suggests it underwent subaerial erosion, and the relatively low refraction velocity is probably from a weathered surface. By contrast, the faster velocity from beneath the midslope depocenter is well within the range of values typical of oceanic Layer 2A. Reflections from acoustic basement are observed at this location with the 700 -in. ${ }^{3}$ air gun used during sonobuoy experiments; these reflectors have the irregular to hyperbolic character associated with (but not unique to) the top of Layer $2 \mathrm{~A}$.

Amplitudes and wavelengths of magnetic anomalies along the Oman margin are clearly a function of depth to this acoustic basement. Where most sharply defined, these anomalies reveal an east-northeast-west-southwest grain that parallels the magnetic fabric of Owen Basin (Fig. 7; Whitmarsh, 1979). Although metamorphic continental crust could produce similar magnetic lineations, such close alignment with those of the deep basin is unlikely. As with the refraction velocities, this information is consistent with, but not diagnostic of, the occurrence of Layer $2 \mathrm{~A}$ within the survey grid. The complex and recently active structures described here argue against a simple Jurassic rifted origin for the southeast Oman margin. The most significant discovery in this regard is the basement high interpreted to be subaerially eroded, magnetically lineated oceanic crust landward of the Siquirah Fault. Although the survey did not extend far enough landward to be certain, it is probable that this feature is bounded on the west by the Masirah Fault. Ophiolites of both Ra's Madrakah and Masirah Island farther north are exactly in line with this structure, and they, too, are bounded on the west by the Masirah Fault. We are virtually certain that the basement structure within the RC2704 survey area originated in the same manner as these exposed mafic complexes. Obduction of Masirah Island occurred sometime between the mid-Cretaceous and middle Eocene, although age of formation on the seafloor and direction of emplacement is unknown (Moseley and Abbotts, 1982). Until these age and directional uncertainties are resolved, it remains possible that the Masirah and Ra's Madrakah ophiolites, plus their submerged counterpart reported here, match the well-documented Semail ophiolites in age and tectonic process. These latter rocks were formed in what is now the Gulf of Oman at about 90 to $80 \mathrm{Ma}$, and $10 \mathrm{Ma}$ later were obducted onto the Arabian Peninsula to form the Oman mountains (Coleman, 1981). The sedimentary blocks comprising the lineation beneath the $1000-\mathrm{m}$ isobath may have been rotated, faulted, and emplaced during this same obduction, but this history is unlikely for two reasons: (1) free-air gravity suggests basement does not follow the structural form of these features and (2) if indeed analogous to the Masirah ophiolites and thrust landward 70 to $80 \mathrm{Ma}$ ago, there is suspiciously little overlying sediment. Considering the evidence of recent offset along Siquirah Fault, plus the very rapid subsidence that led to the thick depocenter beneath the midslope "terrace," another and more recent process has probably affected this part of the margin. Supporting data for this argument are described in the following section.

\section{OWEN BASIN AND A REVISED TECTONIC HISTORY}

Well-defined magnetic anomalies in the West Somali Basin record the Middle Jurassic separation of east and west Gondwanaland (Segoufin, 1978; Rabinowitz et al., 1983). Drilling at DSDP Site 241 in West Somali Basin reached mid-Cretaceous sediment, and accumulation rates extrapolated downward to the basement reflection at $8.1 \mathrm{~s}$ corroborate a Jurassic age. The approach and departure lines of the Oman margin survey yielded data across the southern Owen Basin that demonstrate a distinctly different history to Owen Basin. Specifically, (1) magnetic lineations cannot be matched to the M-series, (2) basement is at a maximum of $6.5 \mathrm{~s}$, and (3) seismic correlations of the deepest reflectors in Owen Basin to those at the bottom of Site 224 on Owen Ridge imply a Late Cretaceous age for this basement (Fig. 10). On the basis of these inferences from Owen Basin, as well as from the recent tectonism along the southeast Oman margin, a new model of regional tectonic history has been proposed (Mountain and Prell, 1987, in press). The previous interpretation maintained that Owen Basin, like West Somali Basin, was originally part of the African plate and formed during the roughly northwest-southeast separation of east and west Gondwanaland. During the Late Cretaceous spreading of India away from Madagascar, Owen Ridge developed as a very long transform fault connecting the roughly east-west protoCarlsberg Ridge with an unknown Tethyan spreading ridge north of the Arabian Peninsula. This resulted in a great age discontinuity across Owen Ridge: Cenozoic crust of the Indian plate was adjacent to Mesozoic crust of the African plate. This ancient boundary became the locus of renewed plate interaction in the Oligocene to Miocene, when spreading in the Gulf of Aden resulted in compression and uplift of Owen Ridge. In this manner, Owen Basin became part of the new Arabian plate, but it retained the record of a Jurassic origin that it shared with the southeast Oman margin.

The data from RC2704 suggest a small but significant modification of this prevailing model. The relative "youth" of Owen Basin and the recent tectonism of the southeast Oman margin discovered from RC2704 data could both be explained if the Late Cretaceous transform connecting the proto-Carlsberg Ridge with a Tethyan equivalent developed along the southeast Oman coastline and not at the modern Owen Ridge (Fig. 11). This would predict that (1) Owen Basin is of Late Cretaceous age in the south, becoming younger toward the north; (2) the southeast coast of Oman was a transform margin in the Late Cretaceous; (3) Late Cretaceous lineaments along the margin very likely were reactivated as transpressional features in the Oligocene to Miocene opening of Aden that also resulted in uplift of Owen Ridge; and (4) the small amount of relative motion between the Indian and Arabian plates presently is shared between the eastern escarpment of Owen Ridge and the southeast Oman margin. Consequently, the abrupt normal faults and deep narrow basins along the margin probably involve transcurrent faulting as well.

\section{ACKNOWLEDGMENTS}

The acquisition and interpretation of data from RC2704 was supported by NSF grant OCE85-11571. This is LDGO contribution no. 4407.

\section{REFERENCES}

Al-Marjeby, A., and Nash, D., 1986. A summary of the geology and oil habitat of the eastern flank hydrocarbon province of South Oman. Mar. Pet. Geol., 3:306-314. 
Barker, P. F., 1966. A reconnaissance survey of the Murray Ridge, Philos. Trans. R. Soc. London, 259A:187-197.

Barnes, N. E., and Normark, W. R., 1985. Diagnostic parameters for comparing modern submarine fans and ancient turbidite systems. In Bouma, A., Normark, W., and Barnes, C. R. (Eds.), Submarine Fans and Related Turbidite Systems: New York (Springer-Verlag), 13-14.

Beydoun, Z. R., 1982. The Gulf of Aden and northwest Arabian Sea. In Nairn, A.E.M., and Stelhi, F. G. (Eds.), The Ocean Basins and Margins: The Indian Ocean: New York (Plenum), 253-313.

Chase, C. G., 1978. Plate kinematics: the Americas, East Africa, and the rest of the world. Earth Planet. Sci. Lett., 37:355-368.

Cochran, J. R., 1981. The Gulf of Aden: structure and evolution of a young ocean basin and continental margin. J. Geophys. Res, B, 86: 263-288.

Coleman, R. G., 1981. Tectonic setting for ophiolite obduction in Oman. J. Geophys. Res. B, 86:2497-2508.

Damuth, J. E., Kolla, V., Follod, R. D., Kowsmannn, R. O., Monteiro, M. C., Gorini, M. A., Palma, J.J.C., and Belderson, R. H., 1983. Distributary channel meandering and bifurcation patterns on Amazon deep-sea fan as revealed by long-range side-scan sonar (GLORIA). Geology, 11:94-98.

DeMets, C., and Gordon, R. G., 1987. Limits on motion along the Owen Fracture Zone. EOS, Trans. Am. Geophys. Union, 68:1473.

Farre, J. A., MacGregor, B. A., Ryan, W.B.F., and Robb, J. M., 1983. Breaching the shelfbreak: passage from youthful to mature phase in submarine canyon evolution. In Stanley, D. J., and Moore, G. T. (Eds.), The Shelfbreak: A Critical Interface on Continental Margins: Spec. Publ. Soc. Econ. Paleontol. Mineral., 33:25-39.

Flood, R. D., 1987. Side echoes from a sinuous fan channel obscure the structure of submarine fan channel/levee systems, Amazon Fan. GeoMar. Lett., 7:15-22.

Flood, R. D., and Damuth, J. E., 1987. Quantitative characteristics of sinuous distributary channels on the Amazon deep-sea fan. Geol. Soc. Am. Bull., 98:728-738.

Gorin, G. E., Racz, L. G., and Walter, M. R., 1982. Late PrecambrianCambrian sediments of Hugf Group, Sultanate of Oman. AAPG Bull., 66:2609-2627.

Kastens, K. A., and Shor, A. N., 1985. Depositional processes of a meandering channel on Mississippi Fan. AAPG Bull., 69:190-202.

Kolla, V., and Coumes, F., 1987. Morphology, internal structure, seismic stratigraphy, and sedimentation of Indus Fan. AAPG Bull., 71: 650-677.

Larson, R. L., Pitman, W. C., Golovchenko, X., Cande, S. C., Dewey, J. F., Haxby, W. F., and LaBrecque, J. L., 1985. The Bedrock Geology of the World: New York (Freemont).

Lisitzin, A. P., 1972. Sedimentation in the World Ocean, with Emphasis on the Nature, Distribution and Behavior of Marine Suspensions: Spec. Publ. Soc. Econ. Paleontol. Mineral., 17.

Matthews, D. H., 1966. The Owen Fracture Zone and the northern end of the Carlsberg Ridge. Philos. Trans. R. Soc. London, 259A:172186.

McKenzie, D., and Sclater, J. G., 1971. The evolution of the Indian Ocean since the Late Cretaceous. Geophys. J. R. Astron. Soc., 24: 437-528.

Minster, J. B., and Jordan, T. H., 1978. Present-day plate motions. J. Geophys. Res. B, 83:5331-5354.
Molnar, P., and Tapponnier, P., 1975. Cenozoic tectonics of Asia: effects of a continental collision. Science, 189:419-425.

Morton, D. M., 1959. The geology of Oman. Proc. World Pet. Congr., 5 th, 227-280.

Moseley, F., 1969. The Upper Cretaceous ophiolite complex of Masirah Island, Oman. Geol. J., 6:293-306.

Moseley, F., and Abbotts, I. L., 1979. The Ophiolite mélange of Masirah, Oman. J. Geol. Soc. (London), 136:713-724.

Mountain, G., and Prell, W., 1987. Leg 117 ODP site survey: a revised history of Owen Basin. EOS, Trans. Am. Geophys. Union, 68:424. in press. A multiphase plate tectonic history of the southeast continental margin of Oman. In Robertson, A.H.F., Searle, M. P., Ries, A. C., and Smewing, J. D. (Eds.), The Geology and Tectonic of the Oman Region: Spec. Publ. Geol. Soc. London.

Norton, I. O., and Sclater, J. G., 1979. A model for the evolution of the Indian Ocean and the breakup of Gondwanaland. J. Geophys. Res. $B, 84: 6803-6830$.

Patriat, P., and Achache, J., 1984. India-Eurasia collision chronology has implications for crustal shortening and driving mechanism of plates. Nature, 311:615-621.

Rabinowitz, P. D., Coffin, M. F, and Falvey, D., 1983. The separation of Madagascar and Africa. Science, 220:67-69.

Segoufin, J., 1978. Anomalies magnétiques mésozoiques dans le bassin de Mozambique. C. R. Acad. Sci., Ser. 3, 287:109-112.

Segoufin, J., and Patriat, P., 1980. Existence d'anomalies mésozoiques dans le basin de Somalie. Implications pour les relations AfriqueAntarctique-Madagascar. C. R. Acad. Sci., Ser. 2, 291:85-88.

Setty, M.G.A.P., 1983. Upwelling along the western Indian continental margin and its geological record: a summary. In Thiede, J., and Suess, E. (Eds.), Coastal Upwelling, Its Sediment Record, Part B: Records of Ancient Coastal Upwelling: NATO Conf. Ser. 4, 10B: 201-216.

Stein, C. A., and Cochran, J. R., 1985. The transition between the Sheba Ridge and Owen Basin: rifting of old oceanic lithosphere. Geophys. J. R. Astron. Soc., 81:47-74.

Sykes, L. R., 1968. Seismological evidence for transform faults, seafloor spreading, and continental drift. In Phinney, R. A. (Ed.), The History of the Earth's Crust: Princeton, NJ (Princeton Univ. Press), 120-150.

Twichell, D. C., and Roberts, D. G., 1982. Morphology, distribution, and development of submarine canyons on the United States Atlantic continental slope between Hudson and Baltimore canyons. Geology, 10:408-412.

Whitmarsh, R. B., 1974. Some aspects of plate tectonics in the Arabian Sea. In Whitmarsh, R. B., Weser, O. E., Ross, D. A., et al., Init. Repts. DSDP, 23: Washington (U.S. Govt. Printing Office), 527536 .

1979. The Owen Basin off the south-east margin of Arabia and the evolution of the Owen Fracture Zone. Geophys. J. R. Astron. Soc., 58:441-470.

Whitmarsh, R. B., Weser, O. E., Ross, D. A., et al., 1974. Init. Repts. DSDP, 23: Washington (U.S. Govt. Printing Office).

Wyrtki, K., 1973. Physical oceanography of the Indian Ocean. In Zeitschel, B. (Ed.), The Biology of the Indian Ocean: New York (SpringerVerlag), 18-36.

Ms 117A-118 


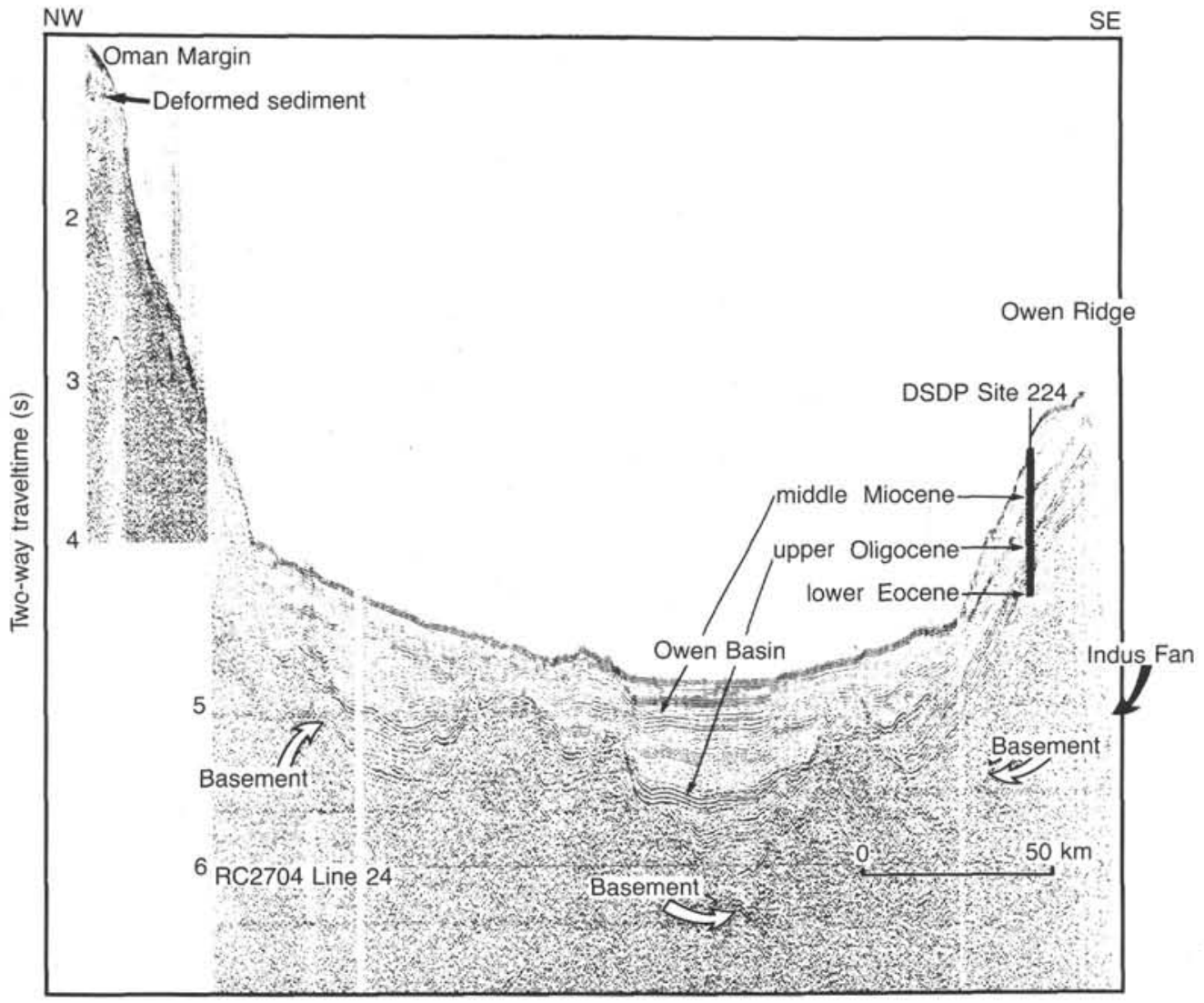

Figure 10. RC2704 line 24 across Owen Basin. Basal sediments at DSDP Site 224 are lower Eocene (Whitmarsh, Weser, et al., 1974), and tracing the corresponding seismic unit along this profile predicts that basement within Owen Basin cannot be much older than basal Paleocene. 

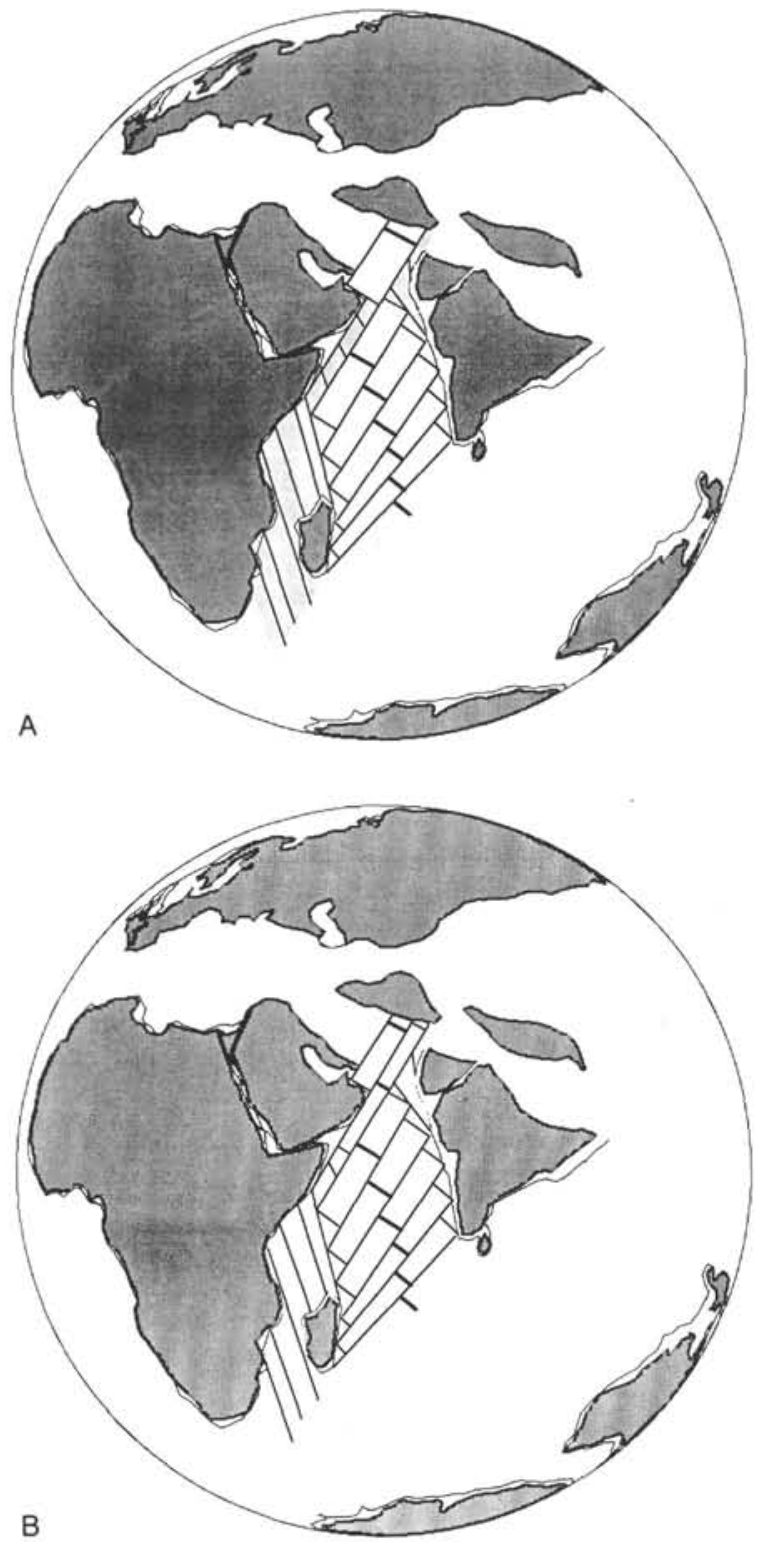

Figure 11. Reconstruction of the northwest Indian Ocean at $50 \mathrm{Ma}$ (mapped by Terra Mobilis) with two possible spreading ridge/plate boundary arrangements sketched in. $\mathbf{A}$. The generally accepted version places the African/Indian plate boundary at Owen Ridge, making the present Owen Basin a remnant of Jurassic to Early Cretaceous age seafloor, similar to other basins of the western Indian Ocean. B. Revised version shows a ridge-ridge transform along the southeast Oman margin (Mountain and Prell, 1987, in press) and predicts that Owen Basin formed during Late Cretaceous spreading of the proto-Carlsberg Ridge. 